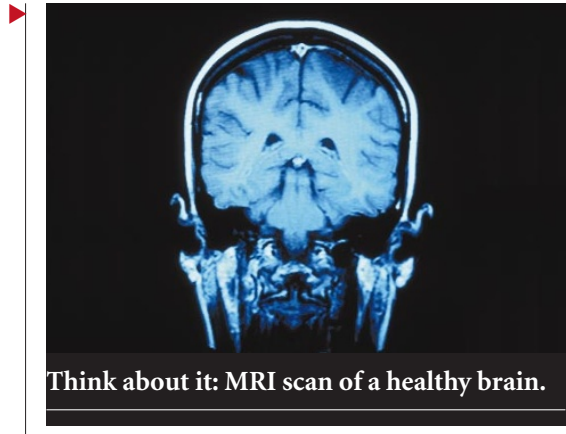

splicing, the move into neuroscience is a shift in direction. "This field is ready for rapid advance," he says. Brain imaging techniques, tools from molecular biology and genetics, insights from the Human Genome Project, and increasing computer power offer huge potential, he says. "The challenge now is to put together a first-rate programme." $\mathrm{He}$ expects the centre to be fully developed within about 10 years.

Sharp is working with Tomaso Poggio, an MIT computational neuroscientist, to chart future research directions. "We will have several years, if not longer, to make decisions about the range of programmes," Sharp says.

The complex will also include the $\$ 20$ million Martinos Imaging Center and the CLM. The imaging centre, to be shared with Harvard University and Harvard Medical School, will work on technologies such as magnetic resonance imaging (MRI), positron emission tomography, and optical imaging. "The idea is to use our technical prowess to advance these tools even further," says Mriganka Sur, who chairs MIT's Department of Brain and Cognitive Sciences.

The CLM, headed by MIT Nobel laureate Susumu Tonegawa, has seven investigators, with five more staff to be hired. It receives about half its funding, US\$3.5 million per year, from the RIKEN Institute, a Japanese government agency - a figure expected to grow to US $\$ 5$ million. Tonegawa predicts that the CLM and the McGovern Institute, working side by side, "will become a major force in neuroscience".

The trick now is figuring out how to make the various pieces fit together. The tentative plan is for the CLM, which investigates learning, memory and neuroplasticity, to continue its emphasis on molecular- and cellular-level processes, while the McGovern will focus on higher-level functions, such as information processing in the brain.

"We want enough overlap so we can interact without duplicating each other's efforts," says Sharp. "It's easy to identify broad themes of what we'd like to see emerge. But we won't know the specifics until we do the work." Steve Nadis

\title{
Indian research budget favours defence
}

\section{New Delhi}

The Indian government has kept its promise to significantly boost the national research budget — but the main beneficiary will be the military.

The recent clash with Pakistan in the Kargil area of the Himalayas, which exposed India's weakness in satellite surveillance and mountain warfare, lies behind the preferential funding increases for military-related research.

Military research now absorbs more than half of the research budget, which, at 120,654 million rupees (US $\$ 2.8$ billion), is nearly 20 per cent up on last year (see table).

A large chunk of the additional funding will be used to develop and build five remotesensing satellites, three of which will be high resolution. Although the government claims that these satellites are intended for both military and civilian applications, sources within the science ministry say their main application will be military.

The defence services had been demanding dedicated satellites for surveillance for some time, says Uday Bhaskar, deputy director of the Institute for Defence Studies and Analysis in New Delhi, adding that the Kargil conflict seems to have clinched it.

The Department of Atomic Energy intends to use part of its additional 2,270 million rupees to develop intense electronbeam machines that can potentially knock out enemy missiles.

It will also use some of the new funds to develop a 500-MW prototype fast breeder reactor which will use plutonium produced by Indian power reactors.

Science secretary Valangiman Ramamurthi says that, although more military research is needed for national security, the scientific community in general is "quite happy" with the budget. "Allocations for almost all science departments have gone up

\begin{tabular}{|lcc|}
\hline \multicolumn{3}{|c|}{ Table: Indian science budget (in million rupees) } \\
\hline \multirow{2}{*}{ Defence } & 1999 & 2000 \\
\hline Space & 20,954 & 22,742 \\
\hline Atomic energy & 17,259 & 20,192 \\
\hline Agriculture & 13,791 & 16,079 \\
\hline Industrial & 13,040 & 14,046 \\
\hline Environment & 8,237 & 9,704 \\
\hline Dept of S\&T & 7,180 & 9,650 \\
\hline Medical & 6,173 & 7,798 \\
\hline Non-conventional energy & 7,519 & 9,139 \\
\hline Information technology & 3,195 & 4,443 \\
\hline Oceanography & 1,950 & 3,920 \\
\hline Biotechnology & 1,067 & 1,580 \\
\hline Total & 1,282 & 1,361 \\
\hline
\end{tabular}

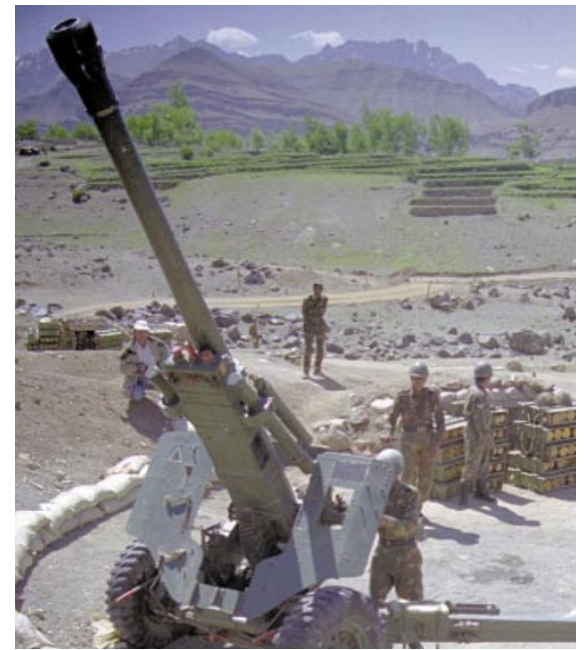

Going great guns: the Indian militia in Kargil.

between 14 and 20 per cent compared to last year," he says.

"Basic research did not get as much as we wanted," he admits, but the government has allocated additional funds for the two new research centres - the National Brain Research Centre (500 million rupees) and the National Centre for Plant Genome Research (350 million rupees), both in New Delhi.

Ramamurthi is particularly happy that 500 million rupees has been earmarked for some of the technology projects identified in the Vision-2020 document prepared in 1997 by the Technology Information Forecasting and Assessment Council, a governmentindustry think-tank. "The money for this has come at the right time," he says. Projects such as the use of fly ash (a waste product from coal-based power stations) as building material and the development of hydrogen as an energy source will now be taken up seriously, he says.

The science budget also provides 500 million rupees for launching the New Millennium Indian Technology Leadership Initiative. Ragunath Mashelkar, secretary to the Department of Scientific and Industrial Research, says this initiative will "focus on four or five areas which would fulfil the national objectives of a global leadership in technology". The government, industry and venture capitalists will team up to accomplish this, he says.

India's 200 patent offices will receive 750 million rupees for modernization. Scientists have particularly welcomed the announcement that universities and research institutes can keep all the royalties earned from patents, amending existing rules requiring patent holders to share royalties with agencies that funded their research. K. S. Jayaraman 